Volume 4

Number 5 Symposium Edition - Artificial

Intelligence and the Legal Profession

Article 3

2018

\title{
Ethics of Using Artificial Intelligence to Augment Drafting Legal Documents
}

David Hricik

Mercer University School of Law, hricik_d@law.mercer.edu

Asya-Lorrene S. Morgan

Mercer University School of Law

Kyle H. Williams

Mercer University School of Law

Follow this and additional works at: https://scholarship.law.tamu.edu/journal-of-property-law

Part of the Intellectual Property Law Commons

\section{Recommended Citation}

David Hricik, Asya-Lorrene S. Morgan \& Kyle H. Williams, Ethics of Using Artificial Intelligence to Augment Drafting Legal Documents, 4 Tex. A\&M J. Prop. L. 465 (2018).

Available at: https://doi.org/10.37419/JPL.V4.I5.3

This Symposia Article is brought to you for free and open access by Texas A\&M Law Scholarship. It has been accepted for inclusion in Texas A\&M Journal of Property Law by an authorized editor of Texas A\&M Law Scholarship. For more information, please contact aretteen@law.tamu.edu. 


\section{The Ethics of Using Artificial Intelligence to Augment Drafting Legal Documents}

By David Hricik, * Asya-Lorrene S. Morgan** Kyle H. Williams***

TABle of Contents

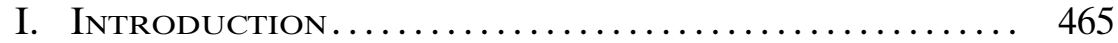

II. What are Augmented Drafting Services? ....... 468

III. The Ethical Issues Created by Augmented

Drating Services ........................... 470

A. Ensuring that the Lawyer or the Lawyer's Client

Owns Intellectual Property Rights in Any Product

Created by Technology........................... 471

1. Copyright Ownership ................... 471

2. Ownership of Patentable Inventions "Invented" by the Service ......................... 474

B. The Attorney must be Competent to Review the

Work, and must remain Responsible to the Client for Work ................................... 474

C. The Fee Must be Reasonable................. 476

D. The Lawyer May Need to Inform the Client that the Lawyer is Using the Service................... 477

E. The Lawyer Must Take Reasonable Care to Protect Client Confidences While the Service is Using the Client's Information and While that Information is Going to and From the Service ..................

F. The Lawyer Must Take Reasonable Care to Avoid Conflicts of Interest ...................... 483

G. Avoid Assisting in the Unauthorized Practice of Law ................................... 483

IV. Conclusion .................................... 484

\section{INTRODUCTION}

Skynet is not and may never be self-aware, but machines are already doing legal research, ${ }^{1}$ drafting legal documents, ${ }^{2}$ negotiating dis-

* Professor of Law, Mercer University School of Law; Of Counsel, Taylor, English, Duma, LLP

** Ms. Morgan is a third-year law student at Mercer University School of Law.

*** Kyle Hindsman Williams is a third-year law student at Mercer University School of Law.

1. See generally, Christian Barker, Artificial Intelligence: Direct and Indirect Impacts on the Legal Profession, 19 N. 3 TortSource 1 (Spring 2017).

2. See Home, Legal Robot, Inc. (2018), https://www.legalrobot.com/ (last visited Feb. 7, 2018).

DOI: https://doi.org/10.37419/JPL.V4.I5.3 
putes such as traffic tickets ${ }^{3}$ and divorce schedules, ${ }^{4}$ and even drafting patent applications. ${ }^{5}$ Machines learn from us, and each other, to augment the ability of lawyers to represent clients - and even to replace lawyers completely. ${ }^{6}$ While it also threatens lawyers' jobs, ${ }^{7}$ the exponential $^{8}$ increase in the capacity of machines to transmit, store, and process data presents the opportunity for lawyers to use these services to provide better, cheaper, or faster legal representation to clients. ${ }^{9}$ By way of familiar example, instead of determining whether a precedential opinion remains "good law" by manually going through multiple books - "Shepardizing ${ }^{10}$ a case" as an older lawyer would put it lawyers can use on-line legal services to instantly learn, not just whether an earlier decision has been limited or overruled, but the depth of analysis given to the issue by a later court opinion. ${ }^{11}$

Because technology may be able to do some tasks better, or at a lower cost, or both, lawyers should use technology when it will, considering the risks, benefit clients. That obligation requires lawyers to

3. See Home, Virtual Courthouse (2018), https://www.virtualcourthouse.com/ (last visited Feb. 7, 2018); SeeSee generally, Balke A. Klinkner, Artificial Intelligence and Virtual Law Offices Expected to be Top Technological Trends Impacting the Legal Profession in 2017, 40 Feb. Wyo. Lawyer 52 (2017).

4. See e.g., What Is Revolve, Resolve Divorce Limited (2018), http://resolve divorce.co.uk/what-is-resolve/ (last visited Feb. 7, 2018). 2017).

5. Home, Specifio (2017), http://specif.io/privacy-policy/ (last visited Sep. 29,

6. See generally, Harry Surden, Machine Learning and Law, 89 Wash. L. Rev. 87 (2014) (explaining machine learning); Daniel E. Harmon, Artificial Intelligence in Law, 34 No. I Law. PC 1 (Jan. 15, 2017) (describing how artificial intelligence both augments and replaces lawyers); Daniel Ben-Ari, Danger Will Robinson, 23 Rich. J.L.Tech 3 (2017) (explaining development of AI and identifying ethical and social implications).

7. See generally, Michael H. Trotter, What's to Become of the Legal Profession (2017); Blair Janis, How Technology is Changing the Practice of Law, 31 No. 3 GPSolo 10 (2014); Daniel Martin Katz, Quantitatve Legal Prediction - or - How I learned to Stop Worrying and Start Preparing for the Data-Driven Future of the Legal Services Industry, 62 Emory L.J. 909 (2013); Christian Barker, Artificial Intelligence: Direct and Indirect Impacts on the Legal Profession, 19 N. 3 TortSource 1 (Spring 2017); Kenneth A. Grady, How are Nontraditional Legal Service Providers Impacting the Average Lawyer's Practice?, 90 Fl. B.J. 44 (Jan. 2016).

8. See Peggy Kubicz Hall, I've Looked at Fees from Both Sides Now: A Perspective on Market-Valued Pricing for Legal Services, 39 Wm. Mitchell L. Rev. 154 (2012).

9. See generally, E. Walters \& J. Asjes, URLS or UPL? Using Software to Close the Access to Justice Gap, Strategic Intelligence for Law Firms 77-100 (Laura Slater ed., Ark Group 2016); Christian Barker, Artificial Intelligence: Direct and Indirect Impacts on the Legal Profession, 19 N. 3 TortSource 1 (Spring 2017); Thomas J. Watson, Malpractice Trends: Claims Decline with Proper Technology Use, 89 Nov. Wis. Law. 53 (2016); Using AI in Practice: It's Practical Now, 42 No. 4. Law Prac. 48 (2016).

10. See generally, Shepardizing- on the Lexis Nexis Services, LexisNexis (2008), https://www.lexisnexis.com\%2Fdocuments \%2FLawSchoolTutorials\%2F2008101508 5048_large.pdf\&usg=AOvVaw1DRrio02q11BwdcWvF8Dq1 (last visited Feb. 7, 2018).

11. See Legal Product Services, Thomson Reuters (2018), https://www.thom sonreuters.com/en/products-services/legal.html (last visited Feb. 7, 2018); Products and Services, Lexis Nexis (2018), http://www.lexisnexis.com/productsandservices/in dustry.asp (last visited Feb. 7, 2018). 
stay "keep abreast of changes in. . . practice, including the benefits and risk associated with relevant technology. ..." ${ }^{12}$ Assessing the benefits and risks of a particular technology obviously requires due diligence into the practical and legal risks of the technology, and comparing that to the benefits it brings to a representation. That assessment requires applying existing ethical rules in a process that can best be analyzed as comprising two stages.

The first step requires determining whether the technology does what it is supposed to do in a reasonably competent manner. For example, just as a lawyer could not use a paralegal to use a form to create the first draft of a contract for a client if the paralegal's work was known to be unreliable or unreasonably expensive, a lawyer cannot use an automated contract drafting service with the same shortcomings. The first step, in other words, requires reasonable efforts by the lawyer to determine the competency of the service. ${ }^{13}$ If the service does not provide competent assistance, the lawyer obviously cannot use it.

The second step requires determining whether a competent service can be used while complying with the ethical obligations of the lawyer, beyond competency. Just as a lawyer must ensure that non-lawyer employees and agents maintain the confidentiality of client information consistent with the lawyer's ethical obligations, ${ }^{14}$ he must do so with all services provided by third parties, including automated services. ${ }^{15}$ Likewise, lawyers must ensure non-lawyer assistants - even those who are independent contractors hired for a particular matter, and not firm employees - must not have conflicts of interest or violations of other ethical rules. ${ }^{16}$

This article focuses on the second step in the due diligence process. While it addresses the question of competency, it focuses more on the further steps a lawyer must take to ensure that the use of the service as part of the representation of a client is consistent with the lawyer's other ethical obligations. While it is important to emphasize that competency requires that the lawyer must be able to assess whether the work product is comparable to what a human would produce, competency is of course a fact-depending inquiry: whether a will is competently drafted turns on the standard of care of a practitioner who drafts wills.

12. See Comment, Model Rules of Prof'l Conduct R. 1.1 (2018) [hereinafter MRPC].

13. See MRPC R. 5.3 (2018). See generally, William E. Foster \& Andrew L. Lawson, When to Praise the Machine: The Promise and Perils of Automated Transactional Drafting, 69 S.C. L. Rev. 597 (2018) (describing the need to assess whether automated drafting services competently draft certain documents).

14. See Comments, MRPC R. 5.2 (2018).

15. Id.

16. See e.g., Jeffrey A. Thaler, An Attorney's Professional Responsibility For NonLawyer Staff And Consultants: Beware!, 18 Maine Bar J. 106 (2002). 
This article focuses more on how a lawyer can determine whether it is ethical to use a competent service that augments document drafting. While addressing how ethical concerns arise across typical practice areas, it highlights a practice area where the risks for violations may be particularly acute because the need for confidentiality is high, ${ }^{17}$ and the potential for undetected conflicts of interest is great: patent practice. ${ }^{18}$ This article identifies the issues, describes the potential risks, and explains what protections a lawyer should look for in the terms of service of an automated legal document drafting site to ensure ethical representation.

\section{What are Augmented Drafting Services?}

Artificial intelligence has been around for a while: "In the legal profession, AI includes programs that have been around for decades and can assist lawyers with certain tasks, including legal research (e.g., Lexis and Westlaw) and, more recently, document review (in the use of analytics and algorithms, including predictive coding, to cull large volumes of documents). ${ }^{19}$

In the same sense, augmented drafting services in a minimal sense have been around for decades: Microsoft Word helps lawyers draft legal documents. To a slight extent, they create some of the same issues that augmented services, as used in this article, create. For example, the thesaurus feature on Word might suggest that a lawyer use a different word than one that is legally required or suggest a slight change that has legal significance (for example, suggesting a change from "recklessly" to "maliciously"). Or, the program might suggest changes to the wording of a form - to avoid passive voice - that changes the meaning of the text in a legally significant way.

The drafting services this article addresses are different in degree and radically so. Augmented drafting services in effect write documents for lawyers, not suggest "improvements" to them as might Word or a similar program. As an author recently explained:

There also has been a growing number of document generating programs, like LegalZoom, that some argue replace the need for lawyers to be part of certain legal processes. It is this group that has generated the most controversy, particularly from a legal ethics perspective. And, although the basic form document software programs offered by companies like LegalZoom may not be AI, as those programs become more sophisticated and offer more than

17. J.H. Reichman, Toward A Third Intellectual Property Paradigm: Article: Legal Hybrids Between the Patent and Copyright Paradigms, 94 Colum. L. Rev. 2432, 2438 (Dec. 1994).

18. Liza Vertinsky, Boundary-Spanning Collaboration and The Limits of Joint Inventorship Doctrine, 55 Hous. L. Rev. 401, 415 (2017).

19. Scott B. Garner, Artificial Intelligence and Its Not-So-Artificial Legal Ethics Implications, 59 Orange County Law. 64, 64-66 (Oct. 2017). 
mere document generation and completion, they may drift into providing AI and, more importantly, the provision of legal services. ${ }^{20}$

The quote above is from six months ago and discusses "basic forms." Yet, the patent drafting service Specifio takes a minimal amount of information from and writes a patent application - complete with drawings. Far from a basic will, the service instantly transforms a few lines of text into about 15 pages of text - and drawings in a few seconds. ${ }^{21}$ Other examples of these services include Ross, ${ }^{22}$ Premonition, and Disco. Exponential change is here.

There are many augmented drafting services. This section surveys some in order to provide an idea of current technology. This will, of course, change rapidly.

LawGeex ${ }^{23}$ is a service intended to automate the review and acceptance of contracts by utilizing "the latest in Artificial Intelligence, machine learning, text analysis and natural language processing to review and understand legal documents." 24 Its service is specifically marketed to in-house counsel as a means of streamlining and efficiently deciphering numerous contracts. ${ }^{25}$

Ross is an augmented drafting platform that provides research assistance to attorneys in the areas of bankruptcy, intellectual property, and labor/employment law. ${ }^{26}$ Ross utilizes "cutting edge NLP technology, pose your research questions like you're talking to another lawyer."27 Additionally, the platform will monitor changes in the aforementioned areas of law, and it will complete legal memorandums regarding the researched information. The risks of ownership and confidentiality are not at issue as with machines that function based on uploaded client confidentiality. Ross does not list a privacy policy listed on their website, but their purported intentions are to: increase research efficiency, drive profitability, accelerate workflow, and provide an intuitive interface. ${ }^{28}$ But, as previously stated the ethical concerns surrounding other augmented technology platforms are not present within Ross as it is a research platform.

20. $I d$.

21. See David Hricik, https://patentlyo.com/hricik/2017/08/machine-patent-drafting.html.

22. See generally, Catherine Nunez, Artificial Intelligence and Legal Ethics: Whether AI Lawyers can Make Ethical Decisions, 20 Tul. J. Tech. \& Intell. Proop. 189 (2017).

23. See generally, Terms of Use, LawGeex, Inc., https://www.lawgeex.com/termsof use/ (last visited Feb. 23, 2018).

24. See generally, About Us, Legalogic Ltd., Inc., https://www.lawgeex.com/about us/ (last visited Feb. 23, 2018).

25. See supra note 23 .

26. See generally, What Is Ross, ROSS Intelligence, Inc., https://rossintelligence .com/ross/ (last visited Feb. 25, 2018).

27. See supra note 29.

28. See generally, Home, ROSS Intelligence, Inc., https://rossintelligence.com/ (last visited Feb. 25, 2018). 
Lex Machina "mine[s] litigation data, [for] insights about judges, lawyers, parties, and the subjects of the cases themselves, culled from millions of pages of litigation information." ${ }^{29}$ This platform is similar to Ross, as both rely on third party information for their augmented drafting technology versus reliance on an attorney providing the necessary information. The benefits of Lex Machina are palpable. It provides "litigation insights on courts, judges, lawyers, law firms, and parties, mined from millions of pages of docket entries and documents, enabling lawyers to predict the outcomes that different legal strategies will produce. Legal Analytics is currently available for patent, trademark, copyright, antitrust, securities, commercial, employment, product liability, and bankruptcy litigation in federal courts." 30

\section{The Ethical Issues Created by Augmented Drafting SERVices}

The analogy to having a machine owned by a third-party to write, or assist in writing, a brief or other legal document is analogous to outsourcing it-but to a computer, not a person. The American Bar Association ("ABA") has addressed the ethical issues created by outsourcing legal work to real human beings. Its opinion provides a good roadmap to identify the issues created here. ${ }^{31}$

An opinion from the ABA addressed the issues that arise when lawyers outsource legal work to third-parties to draft legal documents, and it specifically addressed outsourcing the preparation of patent applications. The ABA stated that among other things, (1) the attorney must be competent to review the work, ${ }^{32}$ and must remain responsible for work ${ }^{33}$ (2) the fee must be reasonable, ${ }^{34}$ (3) the lawyer may need to inform the client that the lawyer is using the services, ${ }^{35}$ (4) client confidences must be protected, ${ }^{36}(5)$ the lawyer must take reasonable care to avoid against conflicts of interest, ${ }^{37}$ and (6) the lawyer must avoid assisting in the unauthorized practice of law. ${ }^{38}$

The same ethical issues arise when the work is outsourced, not to a human being, but to a computer. The ABA recognized that legal services may be outsourced to "independent service providers that are not within their direct control." ${ }^{39}$ While the ABA made that statement

29. See What We Do, Lex Machina, https://lexmachina.com/what-we-do/ (last visited Feb. 25, 2018).

30. See supra note 32 at LM-Overview.

31. See ABA Formal Op. 08-541 (2008).

32. See ABA Formal Op. 08-541; MRPC R. 1.1 (2018).

33. See ABA Formal Op. 08-541; MRPC R. 5.1, 5.3 (2018).

34. See ABA Formal Op. 08-541; MRPC R. 1.5 (2018).

35. See ABA Formal Op. 08-541; MRPC R. 1.6 (2018).

36. See ABA Formal Op. 08-541; MRPC R. 1.6 (2018).

37. See ABA Formal Op. 08-541; MRPC R. 5.7 (2018).

38. See ABA Formal Op. 08-541; MRPC 5.5 (2018).

39. See ABA Formal Op. 08-541. 
when addressing whether a lawyer's reliance on human beings to draft documents is ethical, this article examines reliance on artificial intelligence. The same ethical issues can arise, but we add to that list and begin with a critical question arising from intellectual property law: who owns something written by a computer?

\section{A. Ensuring that the Lawyer or the Lawyer's Client Owns Intellectual Property Rights in Any Product Created by Technology.}

\section{Copyright Ownership}

Under general copyright law, ownership vests initially in the creator of the work, and throughout the founding of our country until recently humans were if not the sole creators were heavily involved in creation of copyrightable works. The fact that a computer assists in creation of a work does not mean it was not created by a human being: presumably, copyright in a book written by a person using a computer does not belong to Microsoft simply because the author wrote the book using a computer. This issue is, however, currently being litigated in Rearden $L L C v$. Disney. ${ }^{40}$ In that case, the plaintiff contends that its software allowed various movie studios to create visual images which the defendants used in their films, without permission, thus violating the plaintiff's copyright in the works. The defendants moved to dismiss, asserting that no copyright subsisted in the owner of the software because otherwise "Adobe or Microsoft would be deemed to be the author-owner of whatever expressive works the users of Photoshop or Word generate by using those programs." ${ }^{41}$

Plainly, the author of a document does not lose copyright protection simply because a computer is involved and makes changes-such as autocorrecting words or suggesting a structure that avoids passive voice. Drafting services create the potential for works to be created without a human providing much, if any, input. Courts generally reason that, unless a statute creates rights in a non-human, such as an animal, such rights do not exist. A recent controversy addressed whether a "selfie" taken by a monkey was subject to copyright protection, and the Ninth Circuit held that unless a statute specifically grants non-humans - in this case, animals - rights, they lacked those rights. ${ }^{42}$ Consistent with this, the U.S. Copyright Office previously stated that

40. See Rearden LLC v. The Walt Disney Co., Case Nos. 3:17-cv-04006-JST (2017).

41. Id.

42. The Ninth Circuit recently held against the monkey, holding that only humans could enforce rights granted by the copyright act. Naruto v. Slater, F.3d (9th Cir. Apr. 23,2018 ), relying on the fact that the Copyright Act did not authorize animals to file suit, and so lacked statutory standing to sue for infringement. 
to qualify for protection, "a work must be created by a human being." 43

However, as the degree of authorship moves from person to computer, and eventually transitions to computer-based creativity entirely, lawyers need to be concerned that courts may continue to insist that humans be primary author as a prerequisite to copyright protection, even though that will erode the incentive to create original works. ${ }^{44}$ Lawyers using services to draft documents must recognize that it may be unclear who owns any copyright in a work, and to take steps to ensure that - if anyone-the lawyer owns it.

Accordingly, a lawyer using an augmented drafting service should review its terms of service to determine whether ownership of copyright in any works created for the lawyer by the service has been addressed. The most effective means to do so is for the service to assign the copyright to the user as part of its terms of service. A second way, almost as effective, is for the service to provide a nonexclusive license to the lawyer and client to use the work as part of its terms of service. Thus, due diligence requires ensuring that the lawyer can use the work without committing copyright infringement.

In this regard, LawGeex's Terms of Services directly address copyright ownership, stating in pertinent part:

Licensing Your Stuff to Us

When you send, upload, or post User Submissions, you still own your stuff but we get certain limited rights to use it. This "limited right to use" is called a "license" in lawyer-speak.

(It cuts both ways! These Terms are also OUR license for you to use OUR stuff! Cool, right?)

By sending us your User Submissions, you're giving us a worldwide, non-exclusive, royalty- free, perpetual, sublicenseable and transferable license to use, reproduce, distribute, prepare derivative works of display, and perform the User Submissions in connection with the Site and our (and our successor's) business, including without limitation for redistributing part or all of the User Submission (and derivative works thereof) in any media formats and through any media channels and you hereby waive any moral rights in your User

43. See U.S. Copyright Office, Compendium of U.S. Copyright Office Practices $\S 306$ (3d ed. 2014) [hereinafter Compendium], http://www.copyright.gov/comp3/docs/ compendium.pdf.

44. See Robert C. Denicola, Ex Machina: Copyright Protection for Computer-Generated Works, 69 Rutgers L. Rev. 251, 257 (Fall 2016). In this regard, Congress has indicated that "copyright is not primarily for the benefit of the author, but primarily for the benefit of the public . . . in that it will stimulate writing." See H.R. Rep. No. 60-2222, at 7 (2d Sess. 1909) Likewise, the Supreme Court has stated, "the primary objective of the Copyright Act is to encourage the production of original literary, artistic, and musical expression for the good of the public." Accord Fox Film Corp. $v$. Doyal, 286 U.S. 123, 127 (1932); Sony Corp. of Am. v. Universal City Studios, Inc., 464 U.S. 417, 429 (1984); Fogarty v. Fantasy, Inc., 510 U.S. 517, 524 (1994). 
Submission, to the extent permitted by law. You also hereby grant each user of the Site or other viewer of the User Submission a nonexclusive right to use, reproduce, distribute, prepare derivative works of, display and perform such User Submissions.

ACK, you say. WTF does all THAT mean?

Basically, it means that we can use your stuff in pretty much any way we want. So if you don't want us to use your stuff, don't send it to us. ${ }^{45}$

Thus, it seems clear that the lawyer will own rights to the work produced by LawGeex. However, as shown below, its user agreement appears to allow it to use confidential information provided by the client in ways that may be unethical.

Without an outright assignment or license, the work-made-for hire doctrine is unlikely to provide complete insulation. A-work-madefor-hire is defined in two ways, only one of which likely will apply to legal documents drafted by a computer: a work-made-for-hire includes "a work prepared by an employee within the scope of his or her employment." ${ }^{6}$ If a work falls within this provision then, "the employer or commissioning party, who pays for the creation of the work, is deemed the author, rather than the employee who may actually have conceived of the work and fixed the expression." 47 However, it is unlikely that a service used by a lawyer to create a document, or the owner of the service, is an "employee" of the lawyer. ${ }^{48}$ Thus, a license or assignment is the best form of protection that can be afforded by the terms of service of an augmented drafting service.

45. See supra note 23 .

46. 17 USCS $\S 101$ (C)(1). The second provision will, by its terms, not apply to typical legal documents:

(2) a work specially ordered or commissioned for use as a contribution to a collective work, as a part of a motion picture or other audiovisual work, as a translation, as a supplementary work, as a compilation, as an instructional text, as a test, as answer material for a test, or as an atlas, if the parties expressly agree in a written instrument signed by them that the work shall be considered a work made for hire. For the purpose of the foregoing sentence, a "supplementary work" is a work prepared for publication as a secondary adjunct to a work by another author for the purpose of introducing, concluding, illustrating, explaining, revising, commenting upon, or assisting in the use of the other work, such as forewords, afterwords, pictorial illustrations, maps, charts, tables, editorial notes, musical arrangements, answer material for tests, bibliographies, appendixes, and indexes, and an "instructional text" is a literary, pictorial, or graphic work prepared for publication and with the purpose of use in systematic instructional activities.

47. See Woodrow Barfield, Intellectual Property Rights in Virtual Environments: Considering the Rights of Owners, Programmers and Virtual Avatars, 39 Akron L. Rev. 649, 662 (2006).

48. See Ward v. Atl. Coast Line R. Co., 362 U.S. 396, 400 (1960); Cmty. for Creative Non-Violence v. Reid, 490 U.S. 730, 751-52 (1989) (citing Restatement (Second) of Agency $\$ 220(2)$ - nonexhaustive list of factors relevant to determining whether a hired party is an employee); 


\section{Ownership of Patentable Inventions "Invented" by the Service.}

Services that draft patent applications create an additional wrinkle. Generally speaking, the person who invents a patentable invention owns it ${ }^{49}$ though the inventor may assign the invention to someone else. A recent article observed that "it is more and more likely that the AI will be the entity taking the inventive step," and so being the "inventor" of a particular invention. ${ }^{50}$ Use of a service to write patent applications creates the potential for the system to "invent" something that is, by itself, a separate patentable invention. ${ }^{51}$ If that happens, who owns that invention?

Currently, U.S. patent laws recognize only individual human beings as inventors - not even "artificial persons" that have become somewhat recognized, such as companies, ${ }^{52}$ let alone machines. ${ }^{53}$ Thus, if the service is an "inventor" the problem becomes the fact that at least as of now only human beings can be an "inventor" under the patent laws. If the courts construe the patent act to allow for inventions by machines, then the machine owns the invention. If not the machine, then perhaps the owner of the system is the "inventor," or, instead, the "list of possible human inventors includes the AI software and hardware developers" and others. ${ }^{54}$

Accordingly, faced with this uncertainty, lawyers using services must address ownership of any inventions made by the system. Counsel should review the terms of service to ensure that the client owns any patentable inventions. Due diligence may require ensuring all patentable inventions conceived of by the system are assigned to the lawyer's client, or at minimum to the lawyer.

\section{B. The Attorney must be Competent to Review the Work, and must remain Responsible to the Client for Work.}

As noted at the outset, a separate step of due diligence is ensuring that the service provides competent work because this is a fact- and practice-specific area. Only a brief word is included here.

49. 35 U.S.C. 17 USCS $§ 101$ (C)(2).

50. Susan Y. Tull, Patenting the Future of Medicine: The Intersection of Patent Law and Artificial Intelligence in Medicine, 10 Landslide No. 3 40, 42 (Jan/Feb 2018). See Liza Vertinsky, Boundary-Spanning Collaboration and the Limits of Joint Inventorship Doctrine, 55 Hou. L. Rev. 401, 429-33 (2018) (examining the open issues arising when humans "collaborate" with machines to invent patentable subject matter).

51. See Ryan B. Abbott, I Think, Therefore I Invent: Creative Computers and the Future of Patent Law, 57 B.C. L. Rev. 1079 (2016).

52. Susan Y. Tull, Patenting the Future of Medicine: The Intersection of Patent Law and Artificial Intelligence in Medicine, 10 Landslide No. 3 40, 42 (Jan/Feb 2018) (citing New Idea Farm Equp. Corp. v. Sperry Corp., 916 F2d 1561, 1566 n.4 (Fed. Cir. 1990)).

53. See Ben Hattenback \& Joshua Glucoft, Patents in an Era of Infinite Monkeys and Artificial Intelligence, 19 Stan. Tech. L. Rev. 32, 426 (2015).

54. Susan Y. Tull, Patenting the Future of Medicine: The Intersection of Patent Law and Artificial Intelligence in Medicine, 10 Landslide No. 3 40, 42 (Jan/Feb 2018) (citing New Idea Farm Equp. Corp. v. Sperry Corp., 916 F2d 1561, 1566 n.4 (Fed. Cir. 1990)). 
In addressing outsourcing to other humans, the ABA stated that compliance with the duty of competency "does not require that tasks be accomplished in any special way," just that "the lawyer who is responsible to the client satisfies her obligation to render legal services competently." 55 In this regard, the challenge with outsourcing is "to ensure that tasks are delegated to individuals who are competent to perform them," and then to ensure that the work product is competently completed.

What this requirement of ensuring competent performance means, of course, is that the lawyer will be responsible for damages caused by legal malpractice. While the lawyer may have a claim against the service provider, because the lawyer is ethically required to, essentially, vouch for the work, the client will have a claim against the lawyer (and, like the lawyer, potentially against the service provider as well)..$^{56}$

Given that the lawyer must be liable to the client for the work, lawyers should ensure that they are competent to review the work of the system. In addition, the lawyer should review the terms of service to determine whether, and to what extent, the lawyer may have a claim against the service. For example, in Kira Systems' Terms of Service, the company narrowly defines specific circumstances in which a user may sue the service:

Except for damages arising from a party's fraud or willful misconduct or misappropriation of intellectual property rights: in no event will (i) either party be liable for indirect, special, incidental or consequential damages, including, but not limited to, loss of profits, loss of revenues, data loss or usage, or loss of opportunities, arising out of or relating to this agreement or the services, even if such party has been advised of the possibility of such damages and (ii) either party's total liability arising out of or relating to this agreement and/ or the services, regardless of cause or theory of recovery, exceed one hundred dollars $(\$ 100)$. To the extent any liability of a party cannot be disclaimed, excluded or limited as aforesaid under applicable law, such liability shall be disclaimed, excluded and limited to the fullest extent permitted under applicable law. ${ }^{57}$

\section{Formal Op. 08-451, supra note 23.}

56. See id. Claims by the lawyer's client against the service provider likely can be grounded in contract law. However, some argue that malpractice claims should be recognized against technology companies which provide legal advice. See David Andrew Kobilka, Backs to the Future: How the Legal Profession Has Ignored the Malpractice Gap Created by Technology, 20 J. Consumer \& CoM. L. 130, 131 (2017) (arguing that malpractice liability "must be extended to all technology companies engaged in the practice of law). Whether the client or the lawyer has the ability to sue the service provider, the client can sue the lawyer for malpractice because the lawyer must be responsible for the work.

57. Kira Systems, Terms of Service (2018), https://kirasystems.com/terms-ofservice/ 
Additionally, Exari Systems provides automation services for larger law firms. In its terms of service, Exari Systems states:

Customer shall indemnify, defend and hold harmless Exari and its Affiliates and their respective employees and agents from and against any loss, cost, damage or expense (but specifically excluding attorneys' fees and costs) in respect of any Claim that relates to (a) Customer Data or any other content or materials provided by Customer or its Affiliates or Authorized Users or (b) the use by Customer or its Affiliates or Authorized Users of the Licensed Software or Exari IP in breach of this Software License Agreement or in violation of applicable law or third party rights. ${ }^{58}$

\section{The Fee Must be Reasonable}

Perhaps the most unusual consequence of applying ethical principles governing human outsourcing to machines concerns money. In addressing outsourcing to humans, the ABA stated that a law firm could charge a client more than the actual cost it paid for a contract lawyer, or non-lawyer. The ABA reasoned that doing so was "not substantively different from the manner in which a conventional law firm bills for the services of its lawyers" because the client does not know the lawyer's salary, benefits, and so on. Yet, the ABA warned that if a firm "decides to pass those costs through to the client as a disbursement, however, no markup is permitted" unless the client agreed otherwise.

Because a lawyer must review the work of an augmented service to ensure its competency-and because the total fee must be reasonable-the first step in the analysis is to ensure that the charge for the service, when combined with the lawyer's fee to review, is reasonable as a whole. To the extent that the lawyer can remain within that overall cap and charge more than the actual cost of the service, the lawyer must have the client agree to those charges.

Thus, lawyers using augmented drafting services should make clear to their clients that they are charging more than the actual out-ofpocket costs of the service (by, for example, adding a percentage onto the fee), and also ensure that the total fee, including those services, are reasonable. Informing the client of such may, of course, require the lawyer to "write off" time when first using a service if its work product, while competent, requires excessive lawyer time to correct. Over time, as the lawyer becomes familiar with its deficiencies or idiosyncrasies that may become unnecessary.

58. Exari Systems, Terms of Service: Indemnification Section 7.2, https://www.exari .com/legal/software-license-terms 


\section{The Lawyer May Need to Inform the Client that the Lawyer is Using the Service}

The ABA recognizes that under some circumstances a lawyer may be required to disclose to a client that it is using third parties to provide legal services. ${ }^{59}$ As noted above, because any charge above the out-of-pocket costs to the lawyer of the service must be disclosed to the client, the requirement of informing the client that the lawyer is using the service may be self-effectuating.

Where disclosure is unnecessary as a part of billing practices, whether disclosure is required would appear to be a fact-dependent duty. However, particularly where a lawyer intends to use an augmented drafting service that is new and unproven, a lawyer should consider carefully whether disclosure is, even if not required, good practice.

\section{E. The Lawyer Must Take Reasonable Care to Protect Client Confidences While the Service is Using the Client's Information and While that Information is Going to and From the Service}

Lawyers using an augmented drafting service must provide information to it to obtain work product. This is, of course, nothing new. When a lawyer uses a computerized legal research service such as Westlaw, if the lawyer provides the client's name and matter (so the expense can be billed) it is disclosing to Westlaw the client's name, the matter, and a query that, no doubt in many instances, may reveal critical confidential information. For example, a search of "what are the damages for fraud" run for a specific client and matter may reveal the client is concerned about being sued for fraud.

Lawyers have a professional responsibility to safeguard client information from unauthorized disclosure, as confidentiality is a bedrock ethical obligation. In this regard, Model Rule 1.6 generally requires lawyers not to reveal confidential information, and the ABA recently emphasized that lawyers must use reasonable care when using technology to ensure confidences are protected.$^{60}$ More specifically, comments added recently to the Model Rules require lawyers to make "reasonable efforts to prevent the inadvertent or unauthorized disclosure" of client information. ${ }^{61}$ This requires lawyers to act "competently" to safeguard client-related information from deliberate or inadvertent disclosure. ${ }^{62}$ Confidential information-either accessed by an unauthorized person or inadvertently disclosed-does not, on its own, constitute a violation of the duty to act competently to protect

59. Formal Op. 08-451, supra note 23.

60. Model Rules of Prof'l Conduct r. 1.6 (Am. Bar Ass'n 1983).

61. Model Rules of Prof'l Conduct r. 3.3(c) (Am. Bar Ass'n 2015).

62. Model Rules of Prof'l Conduct r. 1.6 cmt. 18 (Am. Bar Ass'n 1983). 
confidential information so long as the lawyer has made "reasonable efforts to prevent the access or disclosure." 63

In determining if an attorney's efforts are reasonable, the lawyer should consider the following factors: (1) the sensitivity of the information; (2) the likelihood of disclosure if additional safeguards are not employed; (3) the cost of employing additional safeguards; (4) the difficulty of implementing the safeguards; and (5) the extent to which the safeguards adversely affect the lawyer's ability to represent clients. ${ }^{64}$ As part of due diligence, lawyers must understand that every access point-i.e., computer, tablet, phone, server, and so on- is a "potential entry point for data loss or disclosure [and] must be evaluated for security compliance." ${ }^{\prime 2}$ More specifically, the ABA states the lawyer should: (1) understand the nature of the threat; (2) understand how client information is transmitted and where it is stored; (3) understand and use reasonable electronic security measures; (4) determine how electronic communications about client matters should be protected; (5) label client confidential information; (6) train lawyers and nonlawyer assistants in technology and information security; and (7) conduct due diligence on vendors providing communication technology. ${ }^{66}$

Before using an augmented drafting service, due diligence requires several steps. In this regard, ABA Formal Opinion 08-451 identified several factors lawyers should consider when vetting outside vendors, including: the vendor's security policies and protocols; the use of confidentiality agreements; the vendor's conflicts check system to screen for adversity; and the availability and accessibility of a legal forum for legal relief for violations of the vendor agreement. ${ }^{67}$

Remaining current on the basic features of relevant technology is essential to maintaining professional standards concerning the confidentiality and use of technology. Providing competent representation also means that lawyers must remain up-to-date on changes in the legal landscape. This means that lawyers need to know when there are changes that affect crucial elements of how today's lawyers conduct business on their clients' behalves. This need for continuing education extends to technology commonly used by lawyers. ${ }^{68}$ The ABA emphasized that lawyers do not have to become experts at every aspect of a particular technology but that, at the very least, lawyers "necessarily need to understand basic feature of relevant technology. . .."

While reasonable care to protect client confidences is the minimum standard, a client may require the lawyer use additional security mea-

63. Id.

64. Id. The comment emphasizes that this is not an exhaustive list.

65. ABA Comm'n on Ethics \& Prof'l Responsibility, Formal Op. 477 (2017).

66. Id.

67. Formal Op. 08-451, supra note 23.

68. ABA Comm'n on Ethics \& Prof'l Responsibility, Formal Op. 477R (2017) (discussing the need for competent attorneys to remain abreast of changes in the technological landscape through continuing education). 
sures. ${ }^{69}$ Likewise, state or federal laws applicable to certain types of information may require more than what would be reasonable steps for other forms of client confidences. ${ }^{70}$ On the other hand, clients may agree through informed consent to forego reasonable measures. ${ }^{71}$

In conducting due diligence into whether use of a particular augmented drafting service complies with the lawyer's obligation to use reasonable care to protect client confidences, it helps to break the due diligence analysis down: any confidential information must go from the lawyer to the service, be processed by the service, and then return to the lawyer. A lawyer must use reasonable care to ensure that in transmission, processing, and return, the confidentiality of the information is maintained. The risks of transmission to and from the service are largely the same. We turn to those risks first.

The most secure means to transmit information over the internet to an augmented drafting service would be by using Hyper Text Transfer Protocol Secure ("HTTPS"). Communications sent to and from an augmented drafting service using HTTPS are very secure. ${ }^{72}$ If a service offers this, the lawyer should use it to both send and receive information since it is a reasonable way to transmit most client confidences.

Another way to transmit information is electronic mail ("email"). Generally, email may be in open form or encrypted. Though unencrypted email is generally the preferred way lawyers transmit client confidences, there is doubt as to whether that is reasonable in today's world of cyber-threats and electronic communication devices. ${ }^{73}$ In recently addressing whether encryption is required, the ABA stated that ordinarily encryption is not required, but that either the nature of the information or the degree of risk may require greater measures to meet the reasonableness standard of Rule 1.6(c).

Thus, encrypted email-or plain text email but with encrypted attachments-would also be a reasonable way to send most forms of client confidential information. But plain text email may be insufficient for some types of client confidences. If encryption is available,

69. Model Rules of Prof'l Conduct r. 1.6 cmt. 18 (Am Bar Ass'N 1983).

70. However, any additional imposition of preventative measures by state or federal law go beyond the scope of the MRPC. In patent practice, federal regulations preventing the export of certain technical information may be implicated if a patent drafting service using off-shore computing. See generally, U.S. Dept. of Commerce Bureau of Industry and Security, Export Compliance Guidelines (https://www.bis.doc .gov/index.php/documents/pdfs/1641-ecp/file)

71. Id.

72. See What is an SSL certificate?, DIGICERT, https://www.digicert.com/ssl/ [https:/ /perma.cc/7BU2-GFXA] (last visited Mar. 28, 2018) (explaining the SSL Certificate process).

73. Id. 
using it regardless of the apparent importance of the client's information obviously makes the most sense, but is not necessarily required. ${ }^{74}$

The transmission to and receipt from the service may be reasonable with simple and open email. Encryption may be required, and if available, HTTPS may be as easy and is plainly secure. The other aspects of confidentiality include misuse of the information by the service provider and third-party hacking.

When client confidential information is with the service provider and being processed, it is subject to two risks: hacking by third parties (including unauthorized use by employees of the service) or use by the service that is inconsistent with the lawyer's obligation of confidentiality. In discussing human outsourcing, the ABA reminded lawyers to "act competently to safeguard information relating to the representation of a client against inadvertent or unauthorized disclosure by the lawyer or other persons who are participating in the representation of the client or who are subject to the lawyer's supervision."75 This is because lawyers have a duty under Model Rule 5.3 to make reasonable efforts to ensure that the conduct of non-lawyers under the attorney's supervision is compatible with the professional obligations of the attorney. ${ }^{76}$

When lawyers outsource work and use human beings to perform non-legal services to assist in the practice of law, the ABA advises lawyers to "consider conducting reference checks and investigating the background of . . . any nonlawyer intermediary involved, such as a placement agency or service provider."77 Lawyers may take into account: the education, experience, and reputation of the non-lawyer; the nature of the services provided; the terms of any arrangements concerning the protection of client information; and the legal and ethical environments of the jurisdictions in which the services will be performed, particularly with regard to confidentiality. ${ }^{78}$

Obviously, those obligations are subject to the general rule of reasonableness. Due diligence in the context of augmented drafting services may require the lawyer to investigate the security of the provider's premises (if feasible), computer network, data management system, and perhaps even its recycling and refuse disposal proce-

74. A provider's terms of service may indicate options. For example, Specifio states: "Your patent claims can be e-mailed to Specifio in password-encrypted Microsoft Word documents, which is how Specifio returns draft specifications to you. Specifio runs on secured (data encrypted) U.S.-based servers and does not keep unencrypted copies of Confidential Information, except for the obscured contentstripped versions described below. At every step of the way, Confidential Information is guarded from human eyes or other outside access, as described in this Privacy Policy." Information Security \& Confidentiality Policy, supra note 53.

75. Formal Op. 08-451, supra note 23.

76. Id.

77. Id.

78. Model Rules of Prof'l Conduct r. 5.3 cmt. 3 (1983). 
dures. ${ }^{79}$ Due diligence varies depending on the nature of the information and risk to the client, but may require understanding storage methods used by the service, who has access to the information, and the security measures those people/devices have in place, including requiring periodic password changes, using firewalls, using and keeping up-to-date anti-virus/spyware capabilities, and related procedures. Most service providers today are cloud-based. The ABA stated that this requires lawyers "to recognize and minimize the risk that any outside service provider may inadvertently - or perhaps even advertently - reveal client confidential information to adverse parties or to others who are not entitled to access." 80

In this regard, while "[w]ritten confidentiality agreements are strongly advisable in outsourcing relationships," ${ }^{81}$ blindly relying on a paper policy without some understanding of the reputation and track record of the business is also clearly insufficient. But the terms of service should be reviewed. Some services, as we next show, carefully protect against misuse and disclosure, while others appear to allow use that violates the duty of confidentiality.

With augmented drafting services, the amount and nature of that information may vary, but may radically increase with augmented drafting services. Further, as part of "machine learning," many services seek permission from the lawyer to use the data submitted to improve the service. The lawyer needs to ensure that the permission given to the service conforms with the duty of confidentiality. For example, in their terms of service, Kira Systems states that access to the services they provide is via the Kira Systems website. Users are then told that any interaction with the website and any information collected thereby, is governed by the website Privacy Policy. Kira Systems does inform users that inherent in Kira's structure is the ability for a limited number of Kira employees to access the user's confidential documents. ${ }^{82}$

Thus, a lawyer should examine the terms of service to determine how client information will be used. For example, patent-application drafting service Specifio explains how it uses information:

We may keep and use obscured content-stripped versions of your Confidential Information; however, the content words will be removed from the documents and replaced with nonspecific symbols so that the meaning of the text cannot be ascertained. For example:

The statement

The present disclosure relates to systems and methods for facilitating review of a confidential document by a non-privileged person

79. Formal Op. 08-451, supra note 23.

80. Id.

81. $I d$.

82. Kira Systems, Terms of Service, supra note 52. 
by stripping away content and meaning from the document without human intervention such that only structural and/or grammatical information of the document are conveyed to the non-privileged person

would look something like this:

the p0018 d0017 r0019s to systems and methods for f0000ing r0001 of a c0002 d0003 by a n0004 p0005 by s0006ing a0007 c0008 and m0009 from the d0003 without h0010 i0011 such that only s0012 and/or g0013 i0014 of the d0003 are c0015ed to the n0004 p0005.

We use these obscured content-stripped versions for limited internal purposes only, such as to analyze document structures and word forms, which helps us do things like provide you with better support services and improve the Services.

In addition, Specifio does not train its machine-learning models on the content of any Confidential Information. This helps ensures there is never "cross pollination" between patent applications.

We will not disclose to anyone that you are a Specifio customer or that you are using the Services, without your prior written consent in each instance. ${ }^{83}$

In contrast, the terms of service of LawGeex, quoted above, appear to allow the service to misuse information. Further, its privacy policy ${ }^{84}$ seems to go even further and require the lawyer to "strip out" any confidential information before submission:

All of the stuff you and other users send to us (or to other users), upload, or post (NOT including legal documents to be reviewed by the Tool) is called "User Submissions".

While we'll try to protect the confidentiality of User Submissions that aren't posted publicly, we can't guarantee it.

Also, we can turn your stuff over to others if we get a court order.

Legal documents that you submit to be reviewed by the Tool are called "Legal Submissions." While no online company can absolutely guarantee security, we follow industry standards to protect your information. All Legal Submissions are uploaded using a Secure Socket Layer (SSL) with 128-bit encryption.

For additional protection, you're welcome to strip out the party names and any sensitive terms (like home addresses and prices) before you upload a contract for review.

83. SPECIFIO, Information Security \& Confidentiality Policy (Sept. 6, 2017), https://specif.io/privacy-policy [https://perma.cc/RXD9-A7XT].

84. See generally, Privacy Policy, Legalogic Ltd., Inc., https://www.lawgeex.com/ privacy-policy/ (last visited Feb. 23, 2018). 
These two comparisons show that terms of service-while not the sole criteria-may be sufficient to let a lawyer know that a particular service is inappropriate.

\section{F. The Lawyer Must Take Reasonable Care to Avoid Conflicts of Interest}

In discussing outsourcing to humans, the $\mathrm{ABA}$ recognized that where the vendor represented a client's adversary, there was the potential for misuse of information. Accordingly, it warned that "to minimize the risk of potentially wrongful disclosure, the outsourcing lawyer should verify that the outside service provider does not also do work for adversaries of their clients on the same or substantially related matters; in such an instance, the outsourcing lawyer could choose another provider." 85 When vetting outside human vendors, lawyers should also consider the vendor's conflict check system in order to make a reasonable effort to avoid conflicts of interest. ${ }^{86}$

Applying these principles to augmented services runs into the fact that a machine does not have loyalties. Consequently, the reasons why conflict of interest rules exist do not necessarily apply to machines; a machine can be asked by the lawyer for the plaintiff to write a motion to dismiss and then by the lawyer for the defendant to write a response, and the machine will do as good a job as it can for both. Divided loyalties and data are mutually exclusive.

However, if two parties are using the same system, and if the machine uses confidential information from one party in forming the work product for the other, misuse of confidences-which is one aspect of the duty of loyalty-can be implicated. As noted above, the service's assurances that confidences will not be disclosed-and client identities not revealed-may address most of the policy concerns underlying conflicts of interest rules.

However, lawyers should remain concerned that at the outset of use of these services a court or bar association may apply conflicts of interest rules quite literally. If so, the use of a service that is also being used by an adversary could be viewed as a conflict of interest. Thus, client consent may be required where the lawyer apprises the client that the lawyer is using a service that might also be providing services to direct competitors or adversaries.

\section{G. Avoiding Assisting in the Unauthorized Practice of Law}

Using augmented drafting services also creates the potential for the unauthorized practice of law. ${ }^{87}$ However, that can be avoided if the

85. Id.

86. See id.; Model Rules of Prof'l Conduct r. 5.7 (Аm. Bar Ass'n 1983).

87. See In re Reynoso, 477 F.3d 1117 (9th Cir. 2007); Unauthorized Practice of L. Comm. v. Parsons Tech., Inc., 179 F.3d 956 (5th Cir. 1999); Medlock v. Legalzoom 
lawyer "supervises" the work and is responsible for it: "Ordinarily, an individual who is not admitted to practice law in a particular jurisdiction may work for a lawyer who is so admitted, provided that the lawyer remains responsible for the work being performed and that the individual is not held out as being a duly admitted lawyer." 88

Thus, just as a lawyer can have a non-lawyer paralegal draft a will or other legal document without assisting with the unauthorized practice of law, ${ }^{89}$ so too can a lawyer use a non-lawyer augmented system to do so. That, however, again raises the need for the lawyer to be competent with the work product of the service.

\section{Conclusion}

It may be, as some have said, that existing rules will have to change to account for innovation and the ability of computers to, arguably, practice law. ${ }^{90}$ Until then, this Article provides a framework to apply existing rules to new technologies and help ensure that innovation augments, not hampers, provision of legal services.

It is important to recognize that the lawyers who first use augmented drafting services do so not only at their own peril, but also at the peril of their clients. For those reasons, erring on the side of client disclosure and consent is probably the best and safest course.

.com, Inc., 2013 S.C. LEXIS 362 (Oct. 25, 2013); Janson v. Legalzoom.com, Inc., 802 F. Supp.2d 1053 (W.D. Mo. 2011); see generally, Scott B. Garner, Artificial Intelligence and Its Not-So-Artificial Legal Ethics Implications, 59 Orange Cty. Law. 64-66 (2017).

88. Formal Op. 08-451, supra note 23.

89. See id.; Orange Cty. B. Ass'n. Formal Op. No. 2014-1.

90. See Richard K. Hermann, The Rules of Professional Conduct Will Have to Change to Include "The Ethics of Things", 40 J. Des. St. B. Ass'N 12, 15 (2017), https://issuu.com/dsba/docs/april2017dsbabarjournal [https://perma.cc/Y5QZ-S6GJ]. 